\title{
Peningkatan Sikap Tanggung Jawab dan Hasil Belajar IPS Tentang Pekerjaan Melalui Model Pembelajaran Kooperatif Tipe Numbered Heads Together (NHT) pada Siswa Kelas III SD Negeri 1 Bago Semester 2 Tahun Pelajaran 2017/2018
}

\author{
Anik Suhartini \\ aniksuhartini@gmail.com \\ SD Negeri 1 Bago \\ UPTD Pendidikan Kecamatan Kradenan Kabupaten Grobogan
}

\begin{abstract}
Abstrak
Tujuan penelitian ini mendeskripsikan dan mengetahui Sikap Tanggungjawab dan hasil belajar siswa kelas III SD Negeri 1 Bago semester 2 tahun pelajaran 2017/2018 dalam pembelajaran IPS tentang pekerjaan dapat ditingkatkan melalui model pembelajaran kooperatif tipe Numbered Heads Together (NHT).Tindakan dalam penelitian ini dilakukan 2 siklus. Setiap siklus terdiri 4 tahap : perencanaan, pelaksanaan, pengamatan, dan refleksi. Penelitian dilaksanakan pada bulan Januari sampai dengan April 2018. Proses pengumpulan data, pengolahan data-data, analisis data, pengambilan simpulan, dan penyusunan laporan penelitian membutuhkan waktu selama 4 bulan, yaitu pada bulan Januari sampai dengan April 2018. Tempat untuk mengadakan penelitian di kelas III SD Negeri 1 Bago. Subjek dalam penelitian adalah guru dan seluruh siswa kelas III SD Negeri 1 Bago yang terdiri dari 30 siswa, yang terdiri 18 perempuan dan 12 laki-laki. Hasil belajar IPS melalui model pembelajaran kooperatif tipe Numbered Heads Together (NHT) mengalami peningkatan pada setiap siklus. Hal itu dapat dilihat dari persentase ketuntasan prasiklus $37 \%$, meningkat menjadi $63 \%$ pada siklus I. Pada siklus II persentase ketuntasan kembali meningkat menjadi $97 \%$ dan telah memenuhi indikator keberhasilan yaitu sekurang-kurangnya 80\%. Sikap Tanggung jawab siswa pada penelitian ini mengalami peningkatan. Pada siklus I data hasil pengamatan siswa mendapatkan skor rata-rata 10 dengan kategori cukup. Pada siklus II Sikap Tanggung jawab siswa meningkat dengan perolehan skor 12 dengan ketegori baik. Dari hasil penelitian ini dapat disimpulkan bahwa melalui model pembelajaran kooperatif tipe Numbered Heads Together (NHT) dapat meningkatkan sikap tanggung jawab dan hasil belajar IPS tentang pekerjaan pada siswa kelas III SD Negeri 1 Bago semester 2 tahun pelajaran 2017/2018 secara signifikan.
\end{abstract}

Kata kunci: Tanggung jawab, Hasil Belajar IPS, Numbered Heads Together

\section{PENDAHULUAN}

Pendidikan adalah hak bagi setiap insan manusia, tanpa terkecuali karena negara sudah menjamin warganya untuk mendapatkan pendidikan yang layak. Berdasarkan Undang-undang RI No. 20 tahun 2003 tentang Sistem Pendidikan Nasional, pada pasal 1 disebutkan bahwa pendidikan adalah usaha sadar dan terencana untuk mewujudkan suasana belajar dan proses pembelajaran agar siswa secara aktif mengembangkan potensi dirinya untuk memiliki kekuatan spiritual keagamaan, pengendalian diri, kepribadian, kecerdasan akhlak mulia serta keterampilan yang diperlukan dirinya, masyarakat, bangsa dan negara (Sisdiknas, 2003b). Melalui proses yang panjang pendidikan yang didapatkan secara formal ataupun informal, diharapkan dapat membentuk karakter manusia yang diharapkan bangsa, dalam konteks ini adalah bangsa Indonesia. Pada pasal 3 disebutkan bahwa pendidikan nasional berfungsi mengembangkan kemampuan dan membentuk watak serta peradaban bangsa yang bermartabat dalam rangka mencerdaskan kehidupan bangsa, bertujuan untuk 
berkembangnya potensi siswa agar menjadi manusia yang beriman dan bertakwa kepada Tuhan Yang Maha Esa, berakhlak mulia, sehat, berilmu, cakap, kreatif, mandiri, dan menjadi warga negara yang demokratis serta bertanggung jawab. (Sisdiknas, 2003a) Kurikulum Tingkat Satuan Pendidikan (KTSP) yang tertuang dalam Undang-Undang nomor 20 tahun 2003 pasal 37 ayat 1 menyebutkan bahwa kurikulum pendidikan dasar dan menengah wajib memuat: a) pendidikan agama, b) IImu Pengetahuan Sosial, c) bahasa, d) matematika, e) ilmu pengetahuan alam, f) ilmu pengetahuan sosial, g) seni dan budaya, h) pendidikan jasmani dan olahraga, i) keterampilan/kejuruan, dan j) muatan lokal (Sisdiknas, 2010:20).

Berdasarkan kegiatan observasi dan praktek mengajar yang telah dilakukan peneliti Rendahnya sikap tanggungjawab dan Hasil Belajar IPS tentang Pekerjaan tersebut juga ditemukan di SD Negeri 1 Bago Berdasarkan hasil pengamatan dan wawancara dengankolaborator menemukan siswa belajar sebatas menerima pengetahuan dari guru,kurang dibentuk kerja kelompok secara optimal sehingga partisipasi aktif, minat, motivasi belajar masih kurang, rendahnya kedisiplinan siswa dalam mengikuti pembelajaran. Sedangkan dari pihak guru kurang mengembangkan sifat ingin tahu melalui bertanya dan menemukan sendiri pengetahuan baru, kurang memberikan kesempatan siswa sebagai model pembelajaran, kegiatan refleksi di akhir pertemuan masih kurang, penilaian berdasarkan hasil belajar saja sedangkan proses kurang diperhatikan. Rendahnya hasil belajar didukung nilai IPS siswa Kelas III Semester 2 tahun ajaran 2017 / 2018 masih di bawah Kriteria Ketuntasan Minimal (KKM) sekolah $\geq 70$. Dari 30 siswa, sebanyak 19 siswa atau persentase 63 \%belum mencapai KKM. Selain itu, data juga menunjukkan nilai rata-rata terendah 50 dan tertingggi 80. Berdasarkan data, Sikap tanggungjawab siswa dan Hasil Belajar perlu ditingkatkan agar hasilnya dapat tercapai secara optimal.

Berdasarkan permasalahan tersebut maka peneliti terdorong untuk mengadakan Penelitian Tindakan Kelasdengan mengubah suasana pembelajaran yang lebih kongkrit dan menyenangkan. Salah satu langkah yang dapat membuat siswa aktif pada pembelajaran yaitu dengan menggunakan pendekatan kooperatif. Isjoni menyebut pembelajaran kooperatif dengan istilah pembelajaran gotong royong, yaitu sistem pembelajaran yang memberi kesempatan kepadasiswa untuk bekerjasama dengan siswa lain dalam tugas - tugas yang terstruktur (Isjoni 2010: 23). Pembelajaran kooperatif memiliki dampak positif terhadap siswa yang mempunyai hasil belajarrendah dan dapat meningkatkan hasil belajar serta penyimpanan materi pelajaran yang akan lebih lama. Salah satu pendekatan kooperatif yang sesuai dengan karakteristik siswa SD agar dapat memotivasi siswa untuk mengikuti pembelajaran serta dapat membantu guru menyampaikan materi pembelajaran yang baik adalah model pembelajaran kooperatif tipe Numbered Heads Together (NHT)(Permana, 2016).

Dari ulasan latar belakang tersebut, peneliti bersama tim kolaborasi akan mengadakan penelitian tindakan kelas dengan judul, "Peningkatan Sikap tanggungjawab dan Hasil Belajar IPS tentang Pekerjaan melalui Model Kooperatif Tipe Numbered Heads Together NHT pada Siswa Kelas III SD Negeri 1 Bago Semester 2 Tahun Pelajaran 2017 / 2018.

\section{METODE PENELITIAN}

Penelitian dilaksanakan pada semester 2 tahun pelajaran 2017 / 2018 yaitu bulan Januari sampai dengan April 2017.Proses pengumpulan data, pengolahan data-data, analisis data, pengambilan simpulan, dan penyusunan laporan penelitian membutuhkan waktu selama 4 bulan, yaitu pada bulan Januari sampai dengan April 2018.

Sebagai tempat untuk mengadakan penelitian tentang "Peningkatan Sikap Tanggungjawab dan Hasil Belajar IPS tentang Pekerjaan Melalui Model Pembelajaran Kooperatif Tipe Numbered Heads Together (NHT)pada Siswa Kelas IIISD Negeri 1 Bago Semester 2 Tahun Pelajaran2017 I 2018".Penelitian dilakukan di kelas III SD Negeri 1 Bago Kecamatan Kradenan Kabupaten Grobogan Semester 2 Tahun 2017 / 2018, karena tugas dilakukan sesuai dengan surat tugas mengajar yang diberikan oleh Kepala Sekolah pada semester 2 Tahun 2017 / 2018. 


\section{Anik Suhartini}

Subjek dalam penelitian tindakan kelas yang dilaksanakan di SD Negeri 1 Bago ini adalah guru dan seluruh siswa kelas III SD Negeri 1 Bago yang terdiri dari 30 siswa, yang terdiri 18 perempuan dan 12 laki-laki.

Untuk mendapatkan data yang valid maka peneliti melakukan kolaborasi dengan teman sejawat dengan triagulasi, yaitu data merupakan hasil dari beberapa sumber, diantaranya dari siswa, dan teman sejawat. Selain itu data juga di dapat dengan berbagai teknik diantaranya: teknik dokumentasi untuk mengabil data dengan pedoman pengkajian data dokumen, teknik tes untuk memperoleh informasi tentang perkembangan prestasi pembelajaran melalui soal-soal tes, teknik observasi dengan alat lembar observasi, teknik wawancara melalui alat pedoman wawancara, Catatan lapangan. Dengan perolehan data dari beberapa sumber dan dengan berbagai teknik diharapkan data yang dieproleh akan lebih valid.

Aspek-aspek yang di analisa pada penelitian ini adalah berupa jumlah jawaban yang benar, jumlah jawaban yang salah, nilai rata-rata kelas, ketuntasan belajar secara individu dan ketuntasan belajar secara klasikal. Data kuantitatif berupa hasil belajar kognitif pembelajaran IPS melalui model pembelajaran kooperatif tipe Numbered Heads Together (NHT) yang dianalisis dengan menggunakan teknik analisis deskriptif kuantitatif, yaitu suatu model penelitian yang bersifat menggambarkan kenyataan atau fakta sesuai dengan data yang diperoleh dengan tujuan untuk mengetahui hasil belajar yang dicapai siswa dalam pembelajaran.

Analisis tingkat keberhasilan atau persentase ketuntasan belajar siswa setelah proses belajar mengajar berlangsung pada setiap siklusnya, dilakukan dengan cara memberikan evaluasi atau tes akhir siklus berupa soal tes tertulis. Rancangan dalam penelitian ini adalah penelitian tindakan kelas,langkah-langkah penelitian tindakan kelas dibagi menjadi empat kegiatan, yaitu perencanaan, tindakan, pengamatan/observasi, dan refleksi (Arikunto, 2002)

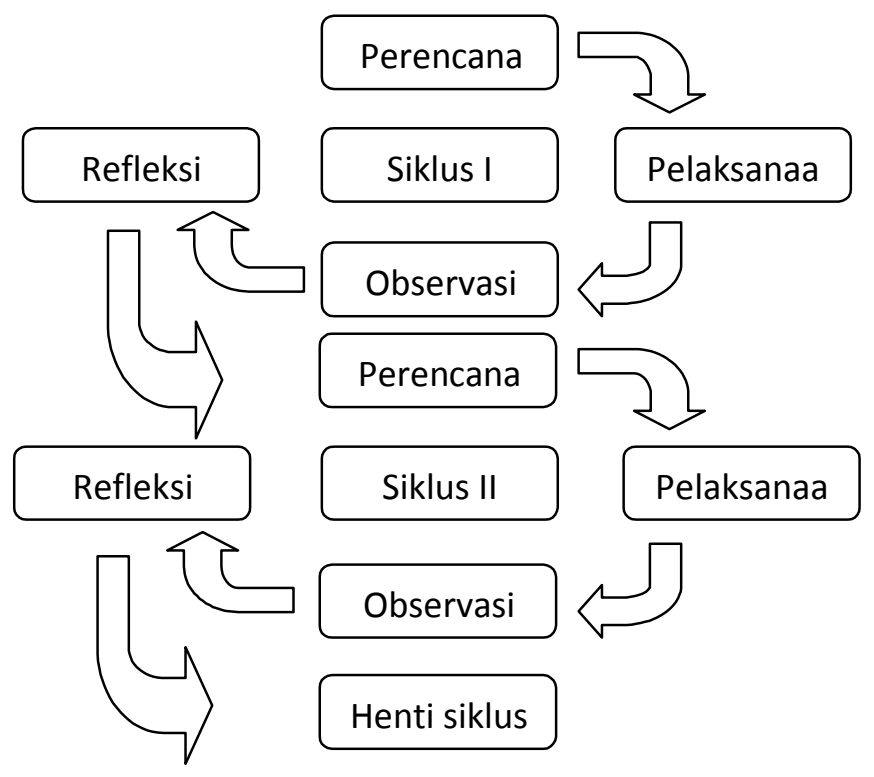

Gambar 1. Siklus Penelitian Tindakan Kelas (Arikunto, 2002:18)

\section{HASIL DAN PEMBAHASAN}

Penelitian ini dilakukan di Sekolah Dasar Negeri 1 BagoUPTD Pendidikan Kecamatan Kradenan, sebuah sekolah yang termasuk dalam wilayah pemerintah daerah Kabupaten Grobogan. Sekolah tersebut dikategorikan sekolah imbas di dabin III Kecamatan Kradenan.Siswanya berasal dari desa Banjardowo. 


\section{Anik Suhartini}

Sekolah Dasar Negeri 1 Bago memiliki sarana belajar yang cukup.Ruang belajar terdapat 6 kelas. Media pembelajaran yang telah dimiliki oleh sekolah tersebut, antara lain media elektronik seperti TV, Komputer, Handycam, dan media-media gambar lainnya.

Jumlah siswa kelas III SD Negeri 1 Bago tahun pelajaran 2017 / 2018 seluruhnya ada 30 siswa, terdiri 18 putri dan 12 putra. Kurikulum yang digunakan di sekolah tersebut pada semester II tahun 2017 / 2018 adalah KTSP berlandaskan Standar Isi Permendiknas No. 22 tahun 2006 dan Kurikulum 13. Dengan kedua kurikulum tersebut, para guru melakukan inovasi pembelajaran dan berupaya mengembangkan kurikulum yang sesuai dengan kondisi daerah demi meningkatnya kualitas proses pembelajaran.

Rendahnya sikap tanggungjawab danhasil belajar IPS tentang pekerjaan ditemukan di SD Negeri 1 Bago . Berdasarkan hasil pengamatan dan wawancara dengankolaborator menemukan siswa belajar sebatas menerima pengetahuan dari guru,kurang dibentuk kerja kelompok secara optimal sehingga partisipasi aktif, minat, motivasi belajar masih kurang, rendahnya kedisiplinan siswa dalam mengikuti pembelajaran. Sedangkan dari pihak guru kurang mengembangkan sifat ingin tahu melalui bertanya dan menemukan sendiri pengetahuan baru, kurang memberikan kesempatan siswa sebagai model pembelajaran, kegiatan refleksi di akhir pertemuan masih kurang, penilaian berdasarkan hasil belajar saja sedangkan proses kurang diperhatikan. Rendahnya hasil belajar didukung nilai IPS siswa kelas III Semester 2 tahun pelajaran 2017 / 2018 masih di bawah Kriteria Ketuntasan Minimal (KKM) sekolah $\geq 70$. Dari 30 siswa, sebanyak 19 siswa atau persentase $63 \%$ belum mencapai KKM. Selain itu, data juga menunjukkan nilai rata-rata terendah50 dan tertingggi 80 . Berdasarkan data, Sikap tanggungjawab dan Hasil Belajar perlu ditingkatkan agar hasilnya dapat tercapai secara optimal.

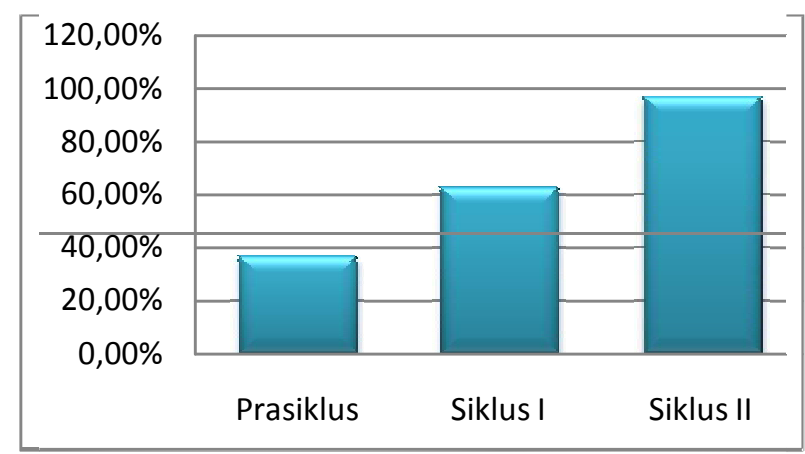

Gambar 2. Perbandingan Persentase Ketuntasan Hasil Belajar Tiap Siklus

Perolehan data pengamatan sikap tanggungjawab siswa pada penelitian ini mendapatkan hasil yang memuaskan. Pada siklus I data hasil pengamatan siswa mendapatkan skor rata-rata 10 dengan kategori cukup dan persentase ketuntasan $53 \%$. Pada pelaksanaan siklus II skor sikap tanggungjawab siswa meningkat. Hal ini terbukti dengan hasil pengamatan sikap tanggungjawab siswa pada siklus II 12dengan kategori baik dan persentase ketuntasan $90 \%$. Dengan demikian dapat disimpulkan bahwa pemerolehan skor sikap tanggungjawab siswa sudah memenuhi indikator keberhasilan. 


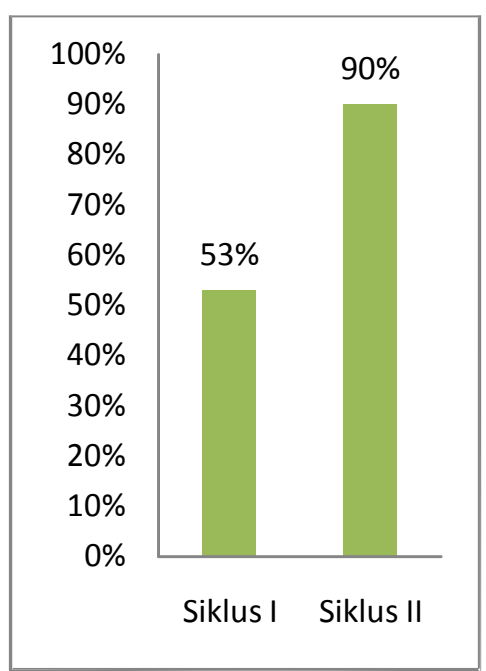

Gambar 3. Perbandingan Persentase Ketuntasan Nilai Sikap tanggungjawab Tiap Siklus.

Hasil belajar siswa pada pembelajaran IPS dengan model pembelajaran kooperatif tipe Numbered heads together (NHT) mengalami peningkatan pada setiap siklus. Hal itu dapat dilihat dari persentase ketuntasan prasiklus hanya $37 \%$, meningkat menjadi $63 \%$ pada siklus I. Kemudian setelah dilakukan perbaikan, pada siklus II persentase ketuntasan kembali meningkat menjadi $97 \%$ dan telah memenuhi indikator keberhasilan.

Perolehan data pengamatan sikap tanggungjawab siswa pada penelitian ini mendapatkan hasil yang memuaskan. Pada siklus I data hasil pengamatan siswa mendapatkan skor rata-rata 10 dengan kategori cukup dan persentase ketuntasan $53 \%$. Pada pelaksanaan siklus II skor sikap tanggungjawab siswa meningkat. Hal ini terbukti dengan hasil pengamatan sikap tanggungjawab siswa pada siklus II 12dengan kategori baik dan persentase ketuntasan $90 \%$. Dengan demikian dapat disimpulkan bahwa pemerolehan skor sikap tanggungjawab siswa sudah memenuhi indikator keberhasilan.

Dapat disimpulkan melalui model pembelajaran kooperatif tipe Numbered heads together (NHT) dapat meningkatkan sikap tanggungjawab dan hasil belajar IPS dalam materi pekerjaan pada siswa kelas III SD Negeri 1 Bago semester 2 tahun pelajaran 2017 /2018. Dari berbagai permasalahan yang muncul pada pelaksanaan tindakan siklus I dapat di atasi pada siklus II.Peneliti dan observer sepakat tindakan dihentikan pada siklus II.

\section{SIMPULAN}

Berdasarkan hasil penelitian mengenai peningkatan Sikap tanggungjawab dan Hasil Belajar IPS tentang Pekerjaan melalui model pembelajaran kooperatif tipe Numbered Heads Together (NHT)pada siswa Kelas III SD Negeri 1 Bago, penulis dapat menarik simpulan sebagai berikut:

Hasil belajar IPS melaluimodel pembelajaran kooperatif tipe Numbered Heads Together (NHT) mengalami peningkatan pada setiap siklus. Hal itu dapat dilihat dari persentase ketuntasan prasiklus $37 \%$, meningkat menjadi $63 \%$ pada siklus I. Pada siklus II persentase ketuntasan kembali meningkat menjadi $97 \%$ dan telah memenuhi indikator keberhasilan yaitu sekurang-kurangnya $80 \%$.

Sikap tanggungjawab siswa pada penelitian ini mengalami peningkatan. Pada siklus I data hasil pengamatan siswa mendapatkan skor rata-rata 10 dengan kategori cukup. Pada siklus II sikap tanggungjawab siswa meningkat dengan perolehan skor 12 dengan ketegori baik. Dengan demikian dapat disimpulkan bahwa pemerolehan skor sikap tanggungjawab siswa sudah memenuhi indikator keberhasilan yaitu mendapatkan skor 11 sampai 15 dengan kategori baik.

Dari hasil penelitian ini dapat disimpulkan bahwa melalui model pembelajaran kooperatif tipe Numbered Heads Together (NHT) dapat meningkatkan sikap tanggungjawab danhasil belajar IPS tentang pekerjaan pada siswa kelas III SD Negeri 1 Bago semester 2 tahun pelajaran 2017 / 2018 secara signifikan. 
Menurut hasil penelitian dan simpulan di atas, maka disarankan:

Guru yang akan menerapkan model pembelajaran kooperatif tipe Numbered Heads Together (NHT) hendaknya dapat memaksimalkan pembelajaran yang dilakukan.

Guru hendaknya lebih menciptakan pembelajaran yang meningkatkan tanggung jawab siswa dalam pemerolehan informasi untuk dirinya sendiri dan untuk kelompoknya sehingga guru dapat lebih meminimalisir sikap tanggungjawab siswa yang mengganggu selama kegiatan pembelajaran berlangsung.

Pemerolehan hasil belajar siswa harus ditingkatkan dengan pembelajaran yang mengaktifkan siswa untuk menggali pengetahuan dari berbagai sumber, media yang inovatif termasuk melalui pengalaman dalam kehidupan sehari-hari siswa.

\section{DAFTAR RUJUKAN}

Aqib, Zaenal dkk.2010.Penelitian Tindakan Kelas. Bandung: CV. Yrama Widya.

Ariani, Niken \& Dany Haryanto.2010.Pembelajaran Multi Media di Sekolah. Jakarta:Prestasi Pustaka.

Arikunto. (2002). Prosedur Penelitian. Rineka Cipta, Jakarta.

Permana, E. P. (2016). PENERAPAN METODE PEMBELAJARAN KOOPERATIF NUMBERED HEADS TOGETHER (NHT) UNTUK MENINGKATKAN HASIL BELAJAR DAN BERPIKIR KRITIS SISWA

PADA MATA PELAJARAN IPS SD. Jurnal Pendidikan Dasar Nusantara, 1(2), 49-58.

Sisdiknas. (2003a). Sistem pendidikan nasional. Jakarta: Direktorat Pendidikan Menengah Umum. Sisdiknas. (2003b). Undang-Undang Republik Indonesia Nomor 20 Tahun 2003 Tentang Sistem

Pendidikan Nasional. Tambahan Lembaran Negara Republik Indonesia Nomor 4301, (c), 1-26. https://doi.org/10.1024/0301-1526.32.1.54

Daryanto.2010. Media Pembelajaran Peranya Sangat Penting Dalam Mencapai Tujuan

Pembelajaran.Yogyakarta: Gava Media

Krathwohl,David R. 2002. A Revision of Bloom's Taxonomy: An Overview. The Ohio State Univetsity

Hadi, Susilo dkk. 2008. Kajian IImu Pengetahuan Sosial.Salatiga: Widya Sari Press

Hamdani.2011.Strategi Belajar Mengajar.Bandung:Pustaka Setia

Huda, Miftahul. 2011. Cooperative Learning: Model, Teknik, Struktur dan Model Terapan. Yogyakarta:

Pustaka Pelajar.

Isjoni, H. 2010. Pembelajaran Kooperatif: Meningkatkan Kecerdasan Komunikasi Antar Siswa.

Yogyakarta: Pustaka Pelajar.

Poerwanti, Endang, dkk. 2008. Asesmen Pembelajaran SD. Jakarta: Depdiknas.

Rifa'i, Achmad dan Catharina Tri Anni. 2009. Psikologi Pendidikan. Semarang: Univeritas Negeri

Semarang Press.

Suprijono, Agus. 2010. Cooperative Learning: Teori dan Aplikasi Paikem. Yogyakarta: Pustaka Pelajar.

Thobroni, Muhammad dan Arif Mustofa. 2011. Belajar dan Pembelajaran: Pengembangan Wacana dan

Praktik Pembelajaran Dalam Pembangunan Nasional. Yogyakarta: Ar-Ruzz Media.

Trianto. 2007. Model-Model pembelajaran Inovatif Berorientasi Konstruktivistik. Jakarta: Prestasi Pustaka.

Uno, Hamzah. 2007. Model pembelajaran Menciptakan Proses Belajar Mengajar yang Kreatif dan

Efektif. Gorontalo: Bumi Aksara

Winataputra, S Udin.2004. Teori Belajar dan Pembelajaran. Jakarta: Universitas Terbuka. 